\title{
Research on Chinese Consumer Behavior of Auto Financing
}

\author{
Zheng Yu' \\ ${ }^{1}$ International College Beijing, China Agricultural \\ University, Beijing, 100083, P.R.China \\ Zhong Yidan ${ }^{1}$ \\ ${ }^{1}$ International College Beijing, China Agricultural \\ University, Beijing, 100083, P.R.China
}

\author{
Liu Xiaohong ${ }^{1}$ \\ ${ }^{1}$ International College Beijing, China Agricultural \\ University, Beijing, 100083, P.R.China \\ Luan Zhiqiang ${ }^{2}$ \\ ${ }^{2}$ Corresponding author, International College Beijing, \\ China Agricultural University, Beijing, 100083, P.R.China
}

\begin{abstract}
With the constantly growing of Chinese financial market, the automobile financial loans market plays a significant role in Chinese consumer's decision on car's purchase. The aim of this paper is to investigate the main factors, including the interest, approval condition, procedure, and the proportion of down payments, which influence consumers' behavior towards automobile financial loans in Beijing. The research uses multiple linear regressions and multiple responses with the SPSS to analyze the data surveyed. The result is given here. The middle age generation, undergraduate group and people in the lower income group or intended to buy low or high price car have a greater possibility of choosing the automobile financial loan and participate in this market. And the main factor influence customers' choice mostly is the interest, approval condition and procedure and down payments.
\end{abstract}

Keywords: automobile financial loans, consumer behavior, SPSS

\section{Introduction}

\subsection{Huge market potential of automobile finance}

Since 1993, China has experienced three periods of development, initial phase, developing phase, and competition phase. Now China ushers in a new age of development - professional phase. What's more, China is a developing country whose GDP has a constantly annual growth rate these years, around 7, according to Trading Economics ${ }^{[1]}$. Furthermore, in terms of the data showed in China association of automobile manufacturers, the portion of automobile loans in China is only around $18 \%$, which is pretty low, compared with other countries ${ }^{[2]}$. It is obvious to see that there is still a huge market potential having never been explored by people in China. In other words, the market is still immature. During the time of changing, many financial products arise in the response to the big economy growth, for instance, car financial loan, which is one of the main manifestations of car finance, have played crucial role in the development of automobile finance.

\subsection{Comparing with western countries}

The main difference between China and western country is that the proportion of car finance loans in western is quite higher than that in China. "Annual vehicle sale value is about 1,300 billion, whose $70 \%$ come from car financial loans; $80 \%$ American people who bought a car chose use loans; $70 \%$ Germany people who bought a car chose use loans; in India, the percentage will be $60 \%$ as well" [3]. There is a mature system in western country, especially in America and Europe. In addition, the system in the U.S. is different from that in Europe. The biggest characteristic of American automobile finance is that manufacturer directly provides the service to consumer, while European manufacturer indirectly lend the car finance loans to the 
customers within the help of banks. Though comparing with China and western countries, and comparing to Europe and America, it suggests that China still has a long way to go increasing market occupation ratio of car financial loan, and improve Chinese automobile finance loan system and policy. This paper will concentrate more on the main factors which influence the consumer's behavior in terms of car financial loans.

\subsection{Restriction or limitation in China system, rules, and Chinese conception of consumerism}

Chinese consumers are accustomed to purchasing things using their own money instead of using loans. Sometimes debts could be regard as a negative thing from Chinese perspective. It is part of Chinese tradition or culture. Furthermore, car finance is a new industry in China. Therefore, China still has a long way to go - increasing market occupation ratio of automobile financial loans and improve the Chinese rule and system of car finance. China could take in the successful experience of foreign country. However, it takes time to make China adapt to them or transform these foreign experiences to the domestic situation. What's more, Chinese credibility system needs to be strengthened and even reestablished. If people do it, the prospect of car financial loans will be better.

In this research, the purpose is to find out the factors that affect the car loan by analyzing customers' behavior and then use the conclusions to help the auto financial companies to identify their positioning and making more correct decisions.

\section{Research Method}

Combine lots of academic papers, car magazines and online websites before finally choose the topic. These sources help researchers to build a basic understanding of auto financial companies in China and help them to decide the research direction.

Design a questionnaire and distribute it to the potential car buyers. Use multiple responses to analyze the age and understanding level of automobile financial loan correlation; education and payment methods correlation; yearly family income and payment correlation, and car price and payment methods correlation

Use multiple linear regression to figure out the main factors that influence car loan. Set 11 possible factors and then do the research with the formula (1):

\section{Data collection}

Totally, in the primary research collected 316 questionnaires about customer's thoughts of the automobile financial loan. The main characteristic of these respondents can be classified as age, educational level and yearly family income, etc..

\subsection{Age}

The main population involving in the research is from 20 to 30 , it takes $69.2 \%$ proportion in total respondent. And then there are people who are younger than 20 years old $(16 \%)$, from 30 to 40 years old $(8 \%)$ and older than 40 years $\operatorname{old}(6 \%)$.

\subsection{Education level}

The main respondents in the research are undergraduates which is $70.9 \%$ of our total respondents. Then there are also some high level education respondents like graduator or higher level people (13\%). Not only the high level educated people, also are there some people in high school (3\%), technical secondary school (6\%) and junior college(7\%).

\subsection{Yearly family income}

In order to consider about the behavior and thought of different level of family in the income aspect, researchers collected the data of family whose income is $<¥ 40,000$ (19\%) , 40,000-60,000 (22\%) , 60,000-120,000 (31\%) , $120,000-240,000 \quad(19 \%)$ and $>240,000 \quad(9 \%)$. And 
respondents are mainly the middle income family which is also the main part of the market and society.

\section{Data Analysis}

\subsection{Age\& Understanding level of automobile financial loan}

By using multiple responses, understand level of automobile financial loan of people in different age. Initially, more people in higher age group like $>40$ know about automobile financial loan compared with the age generation of $<20$ or $20-30$ or $30-40$. Although greater proportion of them knows about the automobile financial loan, these people have not used it.

To the contrary, there are higher rates of people in younger and middle age generation using the automobile financial loan. The people who are younger than 20 or from 20 to30 years old have a higher proportion of having used the automobile financial loan. The people in30-40 age area have the highest proportion of used it. These can be guessedthat the main customers in the automobile financial loan market are these people from 30 to 40 years old. And the young and middle age generation takes a great proportion in using the automobile financial loan in the market.

\subsection{Education \& Payment methods}

After analyzing the relation of education and Intended payment methods by multiple response, can find the payments methods preference of people with different level of education. Totally, people chose they wanted to try the automobile financial loan take $61.4 \%$ portion in the total portion. What's more, the ratio difference between different education levels is not so apparent. But the distribution of these people is not very average in different education level. In general, people with higher education level are more preferable to choose the automobile financial loan compared with choosing pay in full, bank loan and credit card. People with lower education degree like high school and technical secondary school have a lower rate of choosing automobile financial loan which is $50.0 \%$, and $35.3 \%$. In contrary, people received undergraduate and graduator educations have a higher rate of choosing they want to try the automobile financial loan. This people who have higher education level have a higher acceptability about the automobile financial loan.

The undergraduate has highest preference about automobile financial loan. in general, the high educated population has a relatively higher interest in paying by automobile financial loan compared with other payment methods while the market of the people that have lower educational level still has potential develop space to be improved by the effort of financial institutions.

\section{3. Yearly Family Income \& Payment}

It is obviously that yearly family income will influence people's buying behaviors. When people's yearly family income is lower than $¥ 120,000$, nearly $65 \%$ of people are tend to choose the car loan from financial institution. For the people whose yearly family income is between $¥ 120,000$ and $¥ 240,000$, the percentage is $52.5 \%$ and lower than $65 \%$. For the people whose yearly family income is larger than $¥ 240,000$, only $50 \%$ of people tend to choose the car loan from financial institution.

Thus, there is a negative correlation between the yearly family income and people's tendency of car loan from financial institution. What's more, according to the data, most people (more than 50\%) are likely to choose the car loan from financial institution when they want to buy cars. But it is conflicting with the result that only $18 \%$ of people choose the car loan from financial institution in reality.

\section{4. Car Price \& Payment Methods}

When the car price is between $¥ 50,000$ and $¥ 300,000$, most of people will choose the car loan from financial institutions. Meanwhile, when the car price is between $¥ 300,000$ and $¥ 500,000$, the percentage of people that tend to choose the car loan from financial institutions goes 
down and it is $38.5 \%$. For the cars whose price is above $¥ 500,000$, the percentage of people that tend to choose the car loan from financial institutions increases and reaches a very high level $80 \%$.

These data imply that the demand for financial institutions is divided. For the cars that have relatively low price and high price, people will tend to turn to the car loan but for the cars that have median prices, people's car loan demand will decrease.

\section{5. Main Factors that Influence Car Loan}

After data analysis, the R2 and the adjusted R2 of the data is 0.818 and 0.812 . What' $\mathrm{s}$ more, the standard error of the estimate is 0.21166 which means this regression model predicts the data well.

Furthermore, $\mathrm{F}$ is 124.344 and $\mathrm{p}<0.001$ which means there exists a linear regression relation between the dependent variables and independent variables.

From the table 1, the researchers can draw the formula (2):

The above data shows that the factors A, C and D which means approval condition and procedure, interest and the proportion of down payments have relatively strong positive correlation with people's choices of car loan from financial institution. So the companies should pay more attention on these factors.
Table 1: The Main Factors that Influence Car Loan

\begin{tabular}{|c|c|c|c|c|c|}
\hline \multirow[t]{2}{*}{ 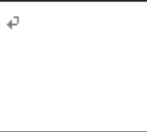 } & \multicolumn{2}{|c|}{$\begin{array}{l}\text { Unstandardized } \\
\text { Coefficients }\end{array}$} & \multirow{2}{*}{$\begin{array}{l}\text { Standardized } \\
\text { Coefficients }\end{array}$} & \multirow[t]{2}{*}{$t$} & \multirow[t]{2}{*}{ Sig. } \\
\hline & $\mathrm{B}$ & $\begin{array}{l}\text { Standard } \\
\text { error }\end{array}$ & & & \\
\hline $\begin{array}{l}\text { Approval } \\
\text { condition and } \\
\text { procedure }\end{array}$ & .284 & .039 & .280 & 7.349 & .000 \\
\hline $\begin{array}{l}\text { Speed of } \\
\text { approval }\end{array}$ & .038 & .026 & .037 & 1.490 & .137 \\
\hline Interest & .494 & .045 & .480 & 11.02 & .000 \\
\hline $\begin{array}{l}\text { Payback } \\
\text { method }\end{array}$ & $\begin{array}{c}- \\
.027 \\
\end{array}$ & .025 & -.028 & -1.085 & 279 \\
\hline $\begin{array}{l}\text { Standard of } \\
\text { service }\end{array}$ & $\begin{array}{c}- \\
.016 \\
\end{array}$ & .030 & -.014 & -540 & 590 \\
\hline $\begin{array}{l}\text { Payback } \\
\text { period }\end{array}$ & . & 年 & .016 & 618 & 7537. \\
\hline $\begin{array}{l}\text { Handling } \\
\text { charge }\end{array}$ & $\begin{array}{c}- \\
.015\end{array}$ & .026 & -.015 & -.582 & 561 \\
\hline $\begin{array}{l}\text { Brand of car } \\
\text { loan }\end{array}$ & $\begin{array}{c}- \\
.010 \\
\end{array}$ & .039 & -.006 & -246 & .806 \\
\hline $\begin{array}{l}\text { The power of } \\
\text { choosing car } \\
\text { brand and } \\
\text { type }\end{array}$ & $\begin{array}{c}- \\
.024\end{array}$ & .031 & -.020 & & .441 \\
\hline Others & $\begin{array}{c}.02 \\
3 \\
\end{array}$ & .125 & .005 & .183 & .855 \\
\hline
\end{tabular}

\section{Conclusion}

There is a great proportion of relatively older generation only know about the automobile financial loan, but have not tried. The currently main customers are still the middle age generation. Besides, the younger generation that under 30 years old plays a significant role in this market as well and may be more and more important in the future. For automobile financial institutions, a good development prospect is existing in the market of young generation. When taking efforts to keep their existing main customer, meddle age generation, they should also pay attention on younger customers in society. They can put more focus on the advertisement in the young generation just like the advertisement on Internet, games and invest in some product that are more suitable for this young people who may do not have too much salary but have the willing to buy car.

The future target customers of automobile financial companies should be the undergraduate group. The financial institutions can develop products that are more suitable for the undergraduate.

The auto financing companies can create more 
programs that focus on the people that have lower family income. For example, the companies can try to lower the interest and lower the requirement standards to attract more potential customers. What's more, the companies also need to do more research to figure out what's the main factor that stop the people choose it.

The auto financing companies can develop some programs that focus on the median price cars to attract more customers. And the companies also can try to increase the diversity of car brand.

It is wise if the companies present more diversified products to lower the interest, simplify the approval condition and procedure and lower the proportion of down payments. These kind of changes will be more effective and can attract lots of customers for the companies.

\section{References}

[1]. Trading Economics, "China GDP Growth Rate" Trading Economics, pp. 1, 2015.4 April. http://www.tradingeconomics.com/china/gdp-growth.

[2]. China Association of Automobile Manufacturer, "Car Finance: The Proportion of China Automobile loan Is Around 18\%,"Caam.com, pp. 1, 2015.24 April. http://www.caam.org.cn/hangye/20140424/140511894 5.html.

[3]. B. Pu, "The Comparison Between Foreign Country and China As Well As Strategy," Southwestern University of Finance and Economics, pp. 6, 2008. 